\title{
Intensitas dan Sosialitas Keberagaman di Lingkungan Kerja
}

\author{
Yusuf Siswantara $^{1}$, Thomas Lingga ${ }^{2}$, Willfridus Demetrius Siga ${ }^{3}$ \\ ${ }^{1}$ Fakultas Filsafat, Universitas Katolik Parahyangan; yusuf.siswantara@unpar.ac.id \\ ${ }^{2}$ Fakultas Ilmu Sosial dan Sastra, Universitas Kebangsaan. \\ ${ }^{3}$ Fakultas Filsafat, Universitas Katolik Parahyangan
}

Received: 27/11/2020

Reviewed: 30/03/2021

Published: $31 / 07 / 2021$

Copyright $\odot 2021$ by the authors (et al) and Jurnal Sosial Humaniora (JSH)

*This work is licensed under the Creative

Commons Attribution International License (CC BY 4.0).

http://creativecommons.org/licenses/by/4.0/ Open Access

\begin{abstract}
Subject Area: Filsafat (Philosophy)
Abstract

Research "intensity and sociality of diversity in the environment or work unit", aims to find indications of work effectiveness and the values of diversity in a pluralistic work environment on work optimization and productivity. This study uses a quantitative approach with a questionnaire as a random sampling instrument. The number of data population is 39 respondents. The correlation of the intensity of diversity values and work practices in a pluralistic environment is the main aspect that supports work effectiveness both internally and externally. Positive influence supports each person to feel safe, comfortable and have very good relationships. Based on the results of the analysis, this study shows that there is a strong and positive correlation between performance and tolerance values in a pluralistic environment with a positive percentage of $93 \%$ and $0.7 \%$ value deviation that does not support the correlation of the two variables.
\end{abstract}

Keywords: Intensity; Sociality; Diversity; Work Environment.

\section{Pendahuluan}

Indonesia mencita-citakan untuk menjadi bangsa yang 'hidup damai dalam perbedaan' atau membangun masyarakat plural dengan semboyan: Bhinneka Tunggal Ika. Dalam masyarakat plural, manusia hidup dan beraktivitas dalam keragaman, baik dalam suku, ras, agama, keyakinan, pandangan politik, dan sebagainya (Mustafa, 2008; Najmina, 2018). Dengan kondisi keragaman tersebut, kemungkinannya adalah perceraian atau persatuan dalam perbedaan; hal tersebut tergantung pada pengelolaan keragaman sosialnya. Urgensi pengelolaan keberagaman sosial mendorong banyaknya penelitian dalam lingkup tersebut. Misalnya adalah interaksi sosial beragama (Karangmalang \& Kabupaten, 2012), pola inter-komunal umat beragama (Sahlan, 2014), eksplorasi tentang hubungan muslim dan nonmuslim baik masyarakat ataupun siswa pelajar (Kusumawardhani, 2013; Rahman et al., 2018), relasi pemuda dalam perspektif toleransi (Kristanti, 2019; Rohmawati et al., 2019), ataupun historisitas sikap toleransi intra-religius (Yuliyanto et al., 2015).

Dalam kerangka pembangunan ekonomi, masyarakat plural tidak hanya mempunyai modal fisik dan modal insani, tetapi juga modal sosial. Menurut Dwi Winanto Hadi Mohammad dkk (Hadi, et al, 2017), "Modal sosial adalah sumber daya yang melekat dalam hubungan sosial antar individu. Salah satu indikator modal sosial adalah sikap percaya dan toleransi”. Sikap percaya dan toleransi adalah suatu 
keniscayaan dalam proses pembangunan, baik negara, bangsa, masyarakat, ataupun korporasi. Sikap toleransi dan percaya tersebut dengan semangat keterbukaan. Hanya melalui pintu keterbukaan itu, intensitas relasi antara di antara anggota masyarakat bisa dikembangkan. Intensitas relasi ini mewujud dalam situasi internal (kebatinan) dan situasi eksternal (institusional, entah formal ataupun non-formal). Artinya, sikap toleransi akan membuka dan mendorong intensitas relasi yang kuat. Buah dari intensitas yang kuat adalah kondisi sosial dalam suasana damai, nyaman, dan situasi kondusif sesuai karakteristik satuan institusi sosial: kedamaian dalam toleransi (Nurkholis, 2017; Riyadi, 2016).

Penelitian berangkat dari kenyataan bahwa kita menyaksikan adanya berbagai indikasi sosial yang mengarah pada rendahnya sikap toleransi sosial. Berdasarkan analisis data BPS, terdapat trend sikap toleransi yang rendah antara tahun 2012 dan tahun 2014. Adanya berbagai tindak kekerasan menjadi indikasi bahwa pengelolaan perbedaan terabaikan atau tidak mendapat perhatian dengan kasus intoleransi pembakaran vihara Tanjung Balai 2016 (Hadi, 2017). Pertikaian atas dasar perbedaan cukup tinggi, diskriminasi \& kekerasan agama (Budianto, 2019). Singkatnya, rendahnya toleransi menjadi warna yang paling mencolok dalam kehidupan berbagsa dan bermasyarakat. Warna kondisi ini mengiring wacana publik dan indikasi rendahnya rasa aman dan damai karena hilangnya kepercayaan dalam satuan lembaga masyarakat yang lebih kecil, dekat, dan lekat dengan aktivitas harian, yaitu lingkungan kerja (Farhan et al., 2020). Lenyapnya kepercayaan dalam lingkungan kerja tentunya akan bisa menurunkan intensitas dan tentunya produktivitas. Oleh karena itu, toleransi dalam lingkungan pekerjaan menjadi masalah yang urgent bagi peneliti untuk menggali intensitas dan sosialitas dalam lingkungan kerja.

Berbagai penelitian mengisyaratkan paradigma bahwa lingkungan kerja bersifat pluralistik, entah disengaja ataupun tidak disengaja (Jacobsson et al., 2020; Messarra, 2014; Shore et al., 2011; Syamsuar \& Ginting, 2020). Untuk itu, terdapat penelitian yang menganalisis hubungan antara diskriminasi, keberagaman, dan pekerjaan yang menjadi sorotan dalam aktivitasnya (Roscigno \& Yavorsky, 2015). Tidak hanya dalam konteks religiositas atau agama, pluralitas dan diskriminasi juga bisa muncul dalam konteks gender (Rigg \& Sparrow, 1994). Dalam semua kondisi keberagaman, terdapat pola sederhana, yaitu: korelasi lurus antara pengelolaan keberagaman dan situasi kerja yang dirasakan dan dialami. Buruknya pengelolaan pluralitas dalam lingkungan kerja akan menjadi bumerang bagi situasi kerja dan produktivitas kerja (Miftahur Rohmaan, 2017). Sebaliknya, pengelolaan yang baik akan menghasilkan buah yang baik dalam terciptanya situasi kerja yang pluralistik (Franco et al., 2007; Miftahur Rohmaan, 2017).

Begitu banyak penelitian tentang toleransi tetapi belum ada eksplorasi penelitian tentang intensitas relasi sosial antara manusia dalam kondisi plural, khususnya dalam dunia kerja. Penelitian ini bertujuan untuk melakukan eksplorasi korelasi intenistas dan sosialitas keberagaman dalam lingkungan kerja. Persoalan penelitian ini dirumuskan dalam beberapa pertanyaan: 1) Apakah terdapat nilai-nilai keberagaman dalam lingkungan kerja? 2) Apakah terdapat sosialisasi atau pengelolaan atas perbedaan/pluralitas oleh lembaga kerja, yaitu fasilitas pendukung dan konkretisasi nilai keberagaman? 3) Apakah individu memiliki rasa bangga/syukur terhadap kondisi pluralis (entitas nilai dasar keberagaman dan sosialitas)? 4) Apakah intenitas nilai keberagaman dirasakan dan dialami dalam 
lingkungan kerja? Fokus penelitian ini akan menghasilkan suatu diskripsi hubungan antara intensitas dan sosialitas dalam kondisi kerja dalam konteks keberagaman. Penelitian dalam topik ini penting bagi pengelolaan suatu lembaga atau komunitas kerja yang pluralistik.

\section{Tinjauan Pustaka}

\section{Sosialitas Manusia \& Ciri-Cirinya}

Pola relasi yang multikultural dan multireligius dalam masyarakat plural mempunyai pendasaran dalam istilah 'sosialitas manusia'. Dwi Susanto (Hadi, 2004) menjelaskan bahwa sosialitas menjadi ciri khas dan istimewa yang membedakan manusia dari makhluk lain (hewan). Selain itu, sosialitas juga menunjukkan identitas dasar manusia sebagai homo socius atau makhluk sosial. Dalam pemahaman ini, manusia pasti berhubungan dengan manusia lain. Dalam hubungan tersebut, manusia memenuhi kodratnya sebagai mansuia.

Ciri-ciri sosialitas mencakup dua hal. Pertama, sosialitas manusia atau hubungan antarmanusia mempunyai dimensi yang sangat luas namun dapat dikatakan bahwa manusia menjadi manusia hanya karena dia bergaul dengan manusia yang lain. Artinya no man is an island. Aristoteles menyebutkan manusia sebagai zoon politicon makhluk sosial sementara itu para filsuf eksistensialis pun menegaskan bahwa eksistensi manusia merupakan materi dalam mitsein (Heidegger) atau co-existence (Gabriel Marcel). Manusia menjadi manusia karena dia bersama dengan yang lain.

Kedua, sosialitas terikat dengan kodrat manusia. Sosialitas manusia merupakan sosialitas yang mempunyai sifat yang terbuka, prospektif, dan mengarah ke masa depan yang lebih baik. Hal itu tentunya sejauh anggota masyarakat menyadari tanggung jawab punya. (Hadi, 2004)

Ketiga, sosialitas manusia mempunyai tiga sebab yaitu 1) hubungan sosial yang terjadi karena kesamaan: baik etnis religi, atau budaya. Jenis hubungan sosial ini terjadi secara alamiah karena lebih banyak berdasarkan ciri bawaan atau hal lain yang diterima tanpa banyak usaha atau upaya. Oleh karena itu, hubungan ini bersifat emosional. Artinya ikatan terbentuk karena faktor internal dari dalam anggota masyarakat itu sendiri. 2) hubungan sosial terjadi karena kebutuhan satu dengan yang lain. Hubungan ini bersifat rasional. Artinya, ada sesuatu eksternal yang menjadi daya dorong dari hubungan tersebut. Secara alamiah, sebenarnya tidak ada hubungan tapi karena faktor kebutuhan, hubungan itu terjadi. Contoh yang paling mudah adalah hubungan dalam kerja. 3) hubungan sosial yang terjadi karena kondisi kebersamaan yang tidak terhindarkan. Keberadaan sekumpulan orang dalam satu wilayah dengan berbagai macam unsur yang berbeda adalah contoh hubungan sosial karena kondisi kesamaan tersebut. Biasa hubungan sosial ini terjadi karena suatu kesepakatan secara sadar untuk (walaupun berbeda) tetapi menyatakan untuk bersama. Dalam filsafat sosial, perantara sosialitas manusia tersebut adalah sesuatu yang transenden (berdasarkan religiositas) ataupun manusia (keputusan rasional insan) (Hadi, 2004). Pemahaman tentang sosialitas manusia di atas mewujud dalam masyarakat yang beragam. Di dalam masyarakat tersebut, akan muncul pola relasi. 


\section{Keberagaman dan Pola Relasi}

Konsep modal fisik, modal insani, dan modal sosial. Modal fisik menyangkut teknologi, barang, alat produksi; modal insani menyangkut manusia dan seluruh daya kemampuannya; modal sosial menyangkut kekuatan relasional antara insan manusia. Asumsi dasarnya adalah bahwa relasi atau hubungan manusia satu dengan manusia lain merupakan kekuatan yang besar dan penting dalam suatu organisasi, baik itu internasional, nasional, masyarakat, keluarga, dan lembaga sosial, seperti korporasi (Hadi, 2017).

Relasi manusia yang satu dengan manusia yang lain akan menghasilkan situasi sosial atau sosialitas dalam satu kelompok. Sebaliknya, warna sosialitas dalam suatu kelompok bisa merupakan komulasi relasi-relasi manusia dalam kelompok tersebut. Suatu warna sosialitas tertentu bisa berpengaruh dan memengaruhi sikap relasi masing-masing manusia sebagai anggota dari kelompok tersebut.

Masyarakat plural merupakan sekumpulan masyarakat yang di dalamnya terdapat unsur-unsur yang berbeda. Keberagaman menjadi ciri khas dan penentu bagi masyarakat plural. Dalam sejarahnya, masyarakat plural sangat rentan dengan sosialitas negatif. Artinya, relasi antaranggota masyarakat mudah memburuk dengan ditandai oleh pertikaian atau bahkan pemusnahan. Kondisi ini terlukis dengan jelas dalam sejarah agama-agama (internal: Kristianitas, Islam, Hindu dan Budha; eksternal: pertikaian antara pemeluk agama), bangsa-bangsa (tragedi kelam Nazi Jerman, misalnya), dan kondisi konflik nusantara yang berdasarkan perbedaan SARA. Dalam kondisi ini, masing-masing masyarakat seolah-olah 'diajari' tentang pola relasi saat menghadapi perbedaan. Kiranya, dalam kerangka tersebut, Herawati dkk (Herawati, 2017) melakukan penelitian pola relasi individu-individu dalam masyarakat yang rentan konflik sosial karena perbedaan.

Menyadari hal di atas, pendidikan karakter menjadi jalan strategis bagi pendidikan multikulutral dan multireligius. Dengan pendidikan karakter, diharapkan terciptalah generasi warga negara yang baik dan mampu menciptakan pola relasi yang tepat dalam masyarakat dan negara yang pluralis (Supriyanto \& Wahyudi, 2017; Utami, 2017). Semua kondisi tersebut akan mendapatkan batu ujian dalam dunia profesional atau dunia kerja di mana di dalamnya berapa banyak unsur yang akan menentukan pola relasi dan pengalaman intensitas relasi dalam lingkungan kerja yang pluralistik.

Seolah-olah membuka kotak Pandora, keberagaman dalam dunia kerja adalah sebuah keniscayaan. Hal itu disebabkan pertama karena dalam dunia kerja dibutuhkan keberagaman atau perbedaan supaya produktivitas dapat terjamin dan kreativitas dapat ditingkatkan. Kedua, dalam dunia kerja, memang terjadi perbedaan dan keragaman dalam tempat kerja sebagai kondisi yang tidak terelakkan sebagaimana telah dijelaskan di atas. Masalahnya adalah dalam dunia kerja yang beragam terdapat ketimpangan dan diskriminasi dalam berbagai bentuk, kesempatan, dan level pekerjaan, entah karena faktor perbedana usia, warna kulit, ras, jenis kelamin, dan faktor-faktor keragaman lainnya. Kondisi ketimpangan ini mencatatkan kesimpulan bahwa dunia kerja yang beragam di satu sisi membawa efisiensi, tetapi di sisi lain sarat dan rentan dengan diskriminasi profesional (Roscigno \& Yavorsky, 2015). 
Melihat kotak Pandora keberagaman tersebut, jelaslah bahwa pengelolaan keberagaman menjadi keniscayaan atau keharusan dalam hidup berbangsa, bernegara, bermasyarakat, dan bahkan berorganisasi layaknya korporasi atau dunia kerja. Artinya, kecerdasan pengelolaan keberagaman akan menjadi modal sosial yang layak untuk diperjuangkan jika suatu komunitas atau lingkungan kerja ingin menuai panen kesuksesan sesuai dengan visi dan misinya. Hal ini sudah tidak perlu diperdebatkan dan tinggal diperjuangkan.

Persaingan, tantangan global, tuntutan kreativitas dalam dunia digital dan disrupsi karena teknologi informasi dalam revolusi industri 4.0 menegaskan kemutlakan pengelolaan keberagaman. Pantulan pengelolaan tersebut tidak lain adalah intensitas relasi dan tindakan sosialisasi keberagaman sebagai implikasi pengelolaan keberagaman. Pertanyaannya bukanlah perlukah keberagaman tetapi bagaimana intensitas toleransi dirasakan individu dalam sosialitas dirinya (hubungan dirinya dengan yang lain) sebagai dampak dari pengelolaan keberagaman tersebut. Banyak penelitian tentang keberagaman dan toleransi, tetapi terasa sepi sunyi penelitian tentang pengalaman individu tentang intensitas dan sosialitasnya dalam lingkungan unit kerja.

\section{Metode Penelitian}

Penelitian ini mendasarkan diri pada model survei sebagaimana dijelaskan oleh Cresswell (Cresswell, 2015). Secara teoretis, metode survei digunakan untuk mendeskripsikan trend masyarakat, untuk mengetahui opini individual tentang suatu kebijakan atau suatu kondisi, atau sarana untuk mengidentifikasi keyakinan dan sikap individual yang penting (misalnya keyakinan mahasiswa tentang perilaku tertentu). Metode survei menyediakan informasi yang berguna untuk mengevaluasi suatu kebijakan tertentu (Creswell, 2015).

Lebih khusus lagi, penelitian menggunakan rancangan cross-sectional survey design di mana pengambilan data dilakukan dalam periode tanggal 10 Agustus 2020 sampai 20 Oktober 2020 untuk mengumpulkan data tentang sikap, pendapat, keyakinan individu tentang pengalaman intensitas dan sosialitas dalam lingkungan kerja yang plural (Creswell, 2015). Rancangan cross sectional survey design dipilih karena rancangan ini pun dapat menyediakan informasi dan rekomendasi tentang kebutuhan yang perlu diperhatikan dalam suatu lembaga, baik spesifik ataupun umum (Creswell, 2015).

Populasi yang ditetapkan dalam penelitian ini adalah pekerja yang bekerja dalam lingkungan unit kerja pendidikan. Jumlah populasi penelitian ini adalah 46 orang. Dengan menggunakan metode Tabel Kretjie, dengan taraf signifikansi $(\alpha)$ 0,01 (1\%), ditentukan minimal sampel sebanak 42 responden. Penelitian melakukan survei dengan sampling random. Pengambilan data dilakukan dengan bentuk kuesioner kepada responden dengan model web-based questionnaires. Penelitian ini mengelompokkan populasi dalam penghantaran link survei (Creswell, 2015) untuk menghindari masalah (bias) metodologis, seperti junk mail (Sills, S.S., \& Song, 2002). Selain itu, untuk meningkatkan peran serta responden, penelitian ini menggunakan sistem campuran dalam menerapkan web-based questionnaires sebagaimana diperingatkan oleh Sill dan Song (Sill dan Song, 2002). 
Dalam operasionalisasi analisis, variabel dibagi menjadi 4 kategori di antaranya: sangat setuju (SS), setuju (S), biasa (B), dan tidak setuju (TS) dan variabel terdiri dari 1) nilai dasar keberagaman, 2) fasilitas yang mendukung terciptanya keberagaman, 3) pengayaan tentang konkretisasi nilai keberagaman, 4) entitas nilai dasar keberagaman dan sosialitas, dan 5) intensitas praktik keberagaman dan sosialitas selama berada di lingkungan kerja atau unit masing-masing. Peneliti mengumpulkan data, membuat analisis, dan membuat kesimpulan di akhir untuk proses analisis hasil. Penelitian korelasional ini menggambarkan suatu pendekatan umum yang berfokus pada penaksiran kovariat di antara variabel yang muncul secara alami yang ditemukan dalam populasi data yang diperoleh. Model pendekatan penelitian ini mencoba mengorelasikan hubungan dua variabel atau lebih.

\section{Hasil dan Pembahasan}

Hasil kuesioner yang dikumpulkan menunjukkan bahwa korelasi antar variabel dan selanjutnya setelah dianalisis untuk mengidentifikasi hasil responden yang berjumlah 39 orang. Adapun data reponden tersebut dikategorikan berdasarkan jenjang pendidikan, jenis kelamin, masa aktif kerja, dan status pekerjaan. Persentase analisis dari data yang dikumpulkan tersebut ditunjukkan dalam bentuk grafik data di bawah ini.

Berdasarkan data responden yang diterima bahwa jenis kelamin termasuk indikator yang digunakan untuk mengukur realitas tentang nilai-nilai keberagaman dan sosialitas dalam lingkungan kerja masingmasing. Berdasarkan jumlah responden 24 pria dan 15 wanita.

Tabel 1. Jumlah Responden

\begin{tabular}{|c|c|}
\hline Pria & Wanita \\
\hline $24(61.53 \%)$ & $15(38.46 \%)$ \\
\hline
\end{tabular}

\section{Ket: Variable I}

Berdasarkan data responden yang diterima bahwa jenjang pendidikan termasuk ndicator yang digunakan untuk mengukur realitas tentang nilai-nilai keberagaman dan sosialitas dalam lingkungan kerja. Sebaran jenjang Pendidikan dari data responden yang dikumpulkan adalah:

Tabel 2. Jenjang Pendidikan

\begin{tabular}{|c|c|c|c|c|}
\hline SMA/sederajat & Diploma (D3) & Sarjana (S1) & Magister (S2) & Doktor (S3) \\
\hline 7 & 4 & 14 & 10 & 4 \\
\hline $17.94 \%$ & $10.25 \%$ & $35.89 \%$ & $25.64 \%$ & $10.25 \%$ \\
\hline
\end{tabular}

\section{Ket:Variabel II}

Berdasarkan data responden yang diterima bahwa status pekerjaan termasuk indikator yang digunakan untuk mengukur realitas nilai-nilai keberagaman dan sosialitas dalam lingkungan /unit kerja masing-masing. Sebaran status pekerjaan dari data responden yang dikumpulkan adalah pekerja tetap, kontrak dan honorer. 
Tabel 3: Status Pekerjaan

\begin{tabular}{cccccc} 
& Status Pekerjaan & \multicolumn{3}{c}{ Lain-lain } \\
\hline Tetap & Kontrak & Honorer & Belum Bekerja & PNS & Pelajar \\
\hline 26 & 5 & 3 & 3 & 1 & 1 \\
$66.66 \%$ & $12.82 \%$ & $7.69 \%$ & $7.69 \%$ & $2.56 \%$ & $2.56 \%$ \\
\hline
\end{tabular}

\section{Ket: Variabel III}

Dari persentase analisis data di atas bahwa status pekerjaan yang tetap sebagai variabel yang akan dianalisis dalam penelitian ini.

Berdasarkan data responden yang diterima bahwa lamanya bekerja termasuk indikator yang digunakan untuk mengukur realitas nilai-nilai keberagaman dan sosialitas dalam lingkungan kerja. Sebaran masa kerja aktif dari data responden yang dikumpulkan dikelompokkan menjadi 4 golongan. Instrumen masa kerja ini tentunya dapat dijadikan sebagai tolak ukur tentang praktik instensitas nilai keberagaman dan sosialitas di lingkungan atau unit kerja masing masing. Jenjang kategori masa kerja adalah kurang dari 3 tahun, 3-5 tahun, 5-10 tahun, lebih dari 10 tahun.

Tabel 4. Masa Kerja

\begin{tabular}{ccccc} 
Masa Kerja / Tahun \\
\hline 0 tahun & $<3$ tahun & $3-5$ tahun & $\begin{array}{c}5-10 \\
\text { tahun }\end{array}$ & $>10$ tahun \\
\hline 3 & 1 & 4 & 9 & 22 \\
$7.69 \%$ & $2.56 \%$ & $10.25 \%$ & $23.07 \%$ & $56.41 \%$ \\
\hline
\end{tabular}

\section{Ket: Variabel IV}

Berdasarkan analisis data masa lama bekerja dapat dinyatakan bahwa esensi tentang nilai-nilai keberagaman dan sosialitas dalam praktik kerja aktif juga mendukung optimalisasi hakikat kerja di lingkungan atau unit masing-masing.

\section{Variabel V: Jenis Unit Kerja}

Berdasarkan data responden yang diterima bahwa jenis unit kerja termasuk indikator yang digunakan untuk mengukur realitas nilai-nilai keberagaman dan sosialitas dalam lingkungan kerja. Sebaran masa kerja aktif dari data responden yang dikumpulkan dikelompokkan menjadi 4 golongan. Instrumen masa kerja ini tentunya dapat dijadikan sebagai tolak ukur tentang praktik instensitas nilai keberagaman dan sosialitas di lingkungan atau unit kerja masing-masing.

\section{Analisis Data}

Hasil analisis data kuesioner dapat dilihat pada tabel berikut di bawah ini:

Gambar 1. Nilai Keberagaman

Q1: Apakah Anda berada di lingkungan/unit kerja yang pluralistik (beragam)?

\begin{tabular}{ccccc} 
SS & S & B & TS & Ket. \\
\hline $12(30.76 \%)$ & $24(61.53 \%)$ & $3(7.69 \%)$ & $0(0 \%)$ &
\end{tabular}

Q2: Apakah sikap toleransi di lingkungan /unit kerja terbina dengan baik?

\begin{tabular}{ccccc} 
SS & S & B & TS & Ket. \\
\hline $17(43.58 \%)$ & $18(46.15 \%)$ & $4(10.25 \%)$ & $0(0 \%)$
\end{tabular}

Q3: Apakah sikap “saling menghormati” di lingkungan/unit kerja Anda tercipta dengan baik?

$\begin{array}{llll}\text { SS } & \text { S } & \text { B } & \text { TS } \\ 18(46.15 \%) & 15(38.46 \%) & 5(12.82 \%) & 1(2.56 \%)\end{array}$


Q4: Apakah Anda bangga berada di lingkungan/unit kerja yang pluralistik?
SS $\mathrm{S}$
B
$20(51.28 \%)$
$12(30.76 \%)$
$7(17.94 \%)$
$0(0 \%)$

Q5: Apakah Anda merasa nyaman berada di lingkungan/unit kerja yang pluralistik?

\begin{tabular}{cccc} 
SS & S & B & TS \\
\hline $15(38.46 \%)$ & $18(46.15 \%)$ & $6(15.38)$ & $0(0 \%)$
\end{tabular}

Q6: Apakah Anda menyadari dengan saling "menghormati" dan "menghargai” rekan kerja yang berbeda keyakinan merupakan motivasi untuk semakin optimal dalam menjalankan tugas?

\begin{tabular}{cccc} 
SS & S & B & TS \\
\hline $20(51.28 \%)$ & $16(41.02 \%)$ & $3(7.69 \%)$ & $0(0 \%)$
\end{tabular}

Gambar 2. Pengayaan

Q1. Apakah di lingkungan/unit kerja Anda ada pengarahan tentang bentuk pelaksanaan tentang "nilai keberagaman"? (seminar, workshop/lokakarya, rekoleksi, dll)

\begin{tabular}{cccc} 
SS & S & B & TS \\
\hline $7(17.94 \%)$ & $17(43.58 \%)$ & $11(28.20 \%)$ & $4(10.25 \%)$
\end{tabular}

Q2. Apakah di lingkungan/unit kerja Anda ada pembiasan nilai-nilai dasar keberagaman?? (bakti sosial, kunjungan, dll).

\begin{tabular}{cccc} 
SS & S & B & TS \\
\hline $10(25.64 \%)$ & $21(53.84 \%)$ & $7(17.94 \%)$ & $1(2.56 \%)$
\end{tabular}

Gambar 3. Fasilitas

Q1. Apakah di lingkungan/unit kerja Anda ada ruang/tempat/sarana untuk melaksanakan ibadah sesuai dengan keyakinan masing-masing?

\begin{tabular}{cccc} 
SS & S & B & TS \\
\hline $5(12.82 \%)$ & $18(46.15 \%)$ & $6(16.66 \%)$ & $9(23.07 \%)$
\end{tabular}

Q2. Apakah di lingkungan/unit kerja Anda ada kegiatan yang berkaitan dengan praktik nilai-nilai dasar keberagaman?

\begin{tabular}{cccc} 
SS & S & B & TS \\
\hline $14(35.89 \%)$ & $22(56.41 \%)$ & $3(7.69 \%)$ & $1(2.56 \%)$
\end{tabular}

Q3. Apakah di lingkungan/unit kerja Anda ada evaluasi pembinaan sesuai dengan keyakinan masing-masing?

\begin{tabular}{cccc} 
SS & S & B & TS \\
\hline $8(20.51 \%)$ & $15(38.46 \%)$ & $8(20.51 \%)$ & $9(23.07 \%)$
\end{tabular}

Gambar 4. Entitas Nilai Dasar Keberagaman

Q1. Apakah Anda bangga dan puas berada di lingkungan/unit kerja yang pluralistik?

\begin{tabular}{cccc} 
SS & S & B & TS \\
\hline $15(38.46 \%)$ & $18(46.15 \%)$ & $6915.38 \%)$ & $0(0 \%)$
\end{tabular}

Q2. Apakah nilai dasar keberagaman di lingkungan/unit kerja Anda terealisasi setiap saat, di lingkungan dan di luar lingkungan kerja?

\begin{tabular}{cccc} 
SS & S & B & TS \\
\hline $11(28.20 \%)$ & $22(56.41 \%)$ & $4(10.25 \%)$ & $2(5.12 \%)$
\end{tabular}

Q3. Apakah Anda selalu mencerminkan nilai dasar keyakinan di lingkungan/unit kerja Anda?

\begin{tabular}{cccc} 
SS & S & B & TS \\
\hline $16(41.02 \%)$ & $18(46.15 \%)$ & $5(12.82 \%)$ & $0(0 \%)$
\end{tabular}


Gambar 5. Intensitas Nilai Dasar Keberagaman

Q1. Apakah Anda setuju, salah satu dampak negatif (buruk) di lingkungan/unit kerja yang pluralistik adalah individualistik/tidak toleran?

\begin{tabular}{cccc} 
SS & S & B & TS \\
\hline $14(35.89 \%)$ & $11(28.20 \%)$ & $3(7.69 \%)$ & $11(28.20 \%)$
\end{tabular}

Q2. Apakah Anda setuju dengan saling menghormati dan menghargai rekan kerja yang berbeda suku dan agama merupakan salah satu bentuk toleransi?

\begin{tabular}{cccc} 
SS & S & B & TS \\
\hline $20(51.28 \%)$ & $18(46.15 \%)$ & $1(2.56 \%)$ & $0(0 \%)$
\end{tabular}

Q3. Apakah Anda selalu meyakini nilai-nilai positif berada di lingkungan/unit kerja yang pluralistik?

\begin{tabular}{cccc} 
SS & S & B & TS \\
\hline $14(35.89 \%)$ & $19(48.71 \%)$ & $5(12.82 \%)$ & $1(2.56 \%)$
\end{tabular}

Berdasarkan hasil data per variabel tersebut di atas dapat dihasilkan akumulasi konkretisasi antarvariabel tentang nilai keberagaman dan sosialitas dalam lingkunga/unit Kerja adalah sebagai berikut:

\begin{tabular}{lcccc}
\multicolumn{5}{c}{ Tabel 5. Akumulasi data per variabel } \\
\hline SS & S & B & TS \\
\hline Variabel \#1 & $102(39.76 \%)$ & $103(40.17 \%)$ & $28(10.92 \%)$ & $1(0.39 \%)$ \\
Variabel \#2 & $17(6.63 \%)$ & $38(14.82 \%)$ & $18(7.02 \%)$ & $5(1.95 \%)$ \\
Variabel\#3 & $27(10.53 \%)$ & $55(21.45 \%)$ & $17(6.63 \%)$ & $19(7.41 \%)$ \\
Variabel\#4 & $42(16.36 \%)$ & $58(22.65 \%)$ & $15(5.85 \%)$ & $2(0.78 \%)$ \\
Variabel \#5 & $48(18.78 \%)$ & $48(18.72 \%)$ & $9(3.51 \%)$ & $12(4.68 \%)$ \\
\hline
\end{tabular}

Berdasarkan akumulasi data tersebut di atas maka dapat dinyatakan sebagai sebuah pendekatan kesimpulan yang mendukung korelasi positif yang sangat besar dan dominan diperlihatkan dari tabel di atas, yaitu variabel Sangat Setuju (SS) dan Setuju (S). Akan tetapi, penyimpangan nilai yang sangat tidak berpengaruh dan bersifat negatif tentang korelasi kedua variabel tersebut juga ditemukan.

\section{Kesimpulan}

Berdasarkan hasil analisis data dari seluruh kuesioner yang telah dianalisis dalam penelitian ini menemukan korelasi yang sangat kuat terdapat pengaruh positif keberagaman dan intensitas nilai dalam bersosialisasi di lingkungan kerja atau unit. Hadir di tengah keberagaman menjadi entitas yang secara tidak langsung menciptakan kosmolitas kehidupan dalam berkarya dan menciptakan kebersamaan yang transparan, mendukung kenyamanan dalam beraktifitas dan membuat efektivitas kerja menjadi optimal dan menyenangkan. Berada di lingkungan pluralisitik dapat memengaruhi kondisi setiap orang yang tentunya akan berindikasi kepada kinerja dan nilai toleransi. Kondisi tersebut akan menjadikan orang merasa tidak nyaman dalam beraktivitas dalam kesehariannya.

\section{Daftar Pustaka}

Budianto, T. (2019). Diskriminasi agama yang berjumlah mayor terhadap agama yang berjumlah minor dalam kebebasan beragama di negara hukum. https://doi.org/10.31219/osf.io/c78qh

Creswell, J. W. (2015). Riset Pendidikan (5th ed.). Penerbit Pelajar Pelajar. 
Dwi Winanto Hadi Mohammad Dokhi Tiodora Hadumaon Siagian Rini Rahani Sukim. (2017). Analisis Faktor-Faktor Yang Mempengaruhi Sikap Toleransi di Indonesia. Pusat Data Dan Statistik $\begin{array}{llll}\text { Pendidikan Dan } & \text { Kebudayaan }\end{array}$ http://publikasi.data.kemdikbud.go.id/uploadDir/isi_FE52CE11-862A-42C3-9527DB09E874C6C4_.pdf

Farhan, M., Husna, R., Rahman, A., Labanihuda, N., \& Rahman, A. (2020). Religious Discrimination among Muslim Employees. Sains Humanika, 8(November 2017), 9-15.

Franco, M., Virgilio, F. Di, \& Pietro, L. Di. (2007). Diversity in Work Groups : Effects on the Level of Conflict. November 2014.

Jacobsson, A., Backteman-Erlanson, S., \& Egan Sjolander, A. (2020). Diversity, preventive work and education-matters of health and well-being in firefighter discourse. International Journal of $\begin{array}{lllll}\text { Qualitative Studies Health and } & \text { Well-Being, }\end{array}$ https://doi.org/10.1080/17482631.2020.1817661

Karangmalang, M., \& Kabupaten, K. (2012). INTERAKSI SOSIAL ANTAR UMAT BERAGAMA (STUDI KASUS PADA MASYARAKAT KARANGMALANG KEDUNGBANTENG KABUPATEN TEGAL). Journal of Educational Social Studies, 1(2).

Kristanti, A. A. S. A. (2019). PERAN FORUM KERUKUNAN UMAT BERAGAMA (FKUB) DALAM MENJAGA KERUKUNAN ANTARUMAT BERAGAMA DI KABUPATEN SIDOARJO. Kajian Moral Dan Kewarganegaraan, 07, 768-782.

Kusumawardhani, A. (2013). INTERAKSI SOSIAL ANTARA SISWA MUSLIM DENGAN SISWA NON MUSLIM DI SMA KATOLIK YOS SOEDARSO PATI. JURUSAN SOSIOLOGI DAN ANTROPOLOGI FAKULTAS ILMU SOSIAL UNIVERSITAS NEGERI SEMARANG.

Messarra, L. C. (2014). Religious Diversity at Work: The Perceptual Effects of Religious Discrimination on Employee Engagement and Commitment. Contemporary Management Research, 10(1), 59-80. https://doi.org/10.7903/cmr.12018

Miftahur Rohmaan, M. R. (2017). INTERNALISASI NILAI-NILAI SOSIO-KULTURAL A . Pendahuluan dunia . Kenyataan ini dapat dilihat dari kondisi sosio-kultural maupun dipisahkan dari keragaman budaya, adat istiadat, bahasa, dan. Edukasia: Jurnal Penelitian Pendidikan Islam, $12(1), 31-56$.

Mustafa, M. (2008). PLURALITAS DAN TANTANGANNYA. Al-'Adl, 1(2), 1-24.

Najmina, N. (2018). Pendidikan Multikultural Dalam Membentuk Karakter Bangsa Indonesia. Jupiis: Jurnal Pendidikan Ilmu-Ilmu Sosial, 10(1), 52. https://doi.org/10.24114/jupiis.v10i1.8389

Nurkholis, A. (2017). Merajut Damai dalam Kebinekaan. Elex Media Komputindo.

Rahman, R., Ushuluddin, F., Dan, F., Islam, U., \& Alauddin, N. (2018). INTERAKSI SOSIAL MASYARAKAT MUSLIM DAN NON- MUSLIM DI KELURAHAN BALANGNIPA (Skripsi). FAKULTAS USHULUDDIN FILSAFAT DAN POLITIK UNIVERSITAS ISLAM NEGERI ALAUDDIN.

Rigg, C., \& Sparrow, J. (1994). Gender, Diversity and Working Styles. Women in Management Review, 
9(1), 9-16. https://doi.org/10.1108/09649429410050971

Riyadi, H. (2016). KOEKSISTENSI DAMAI DALAM MASYARAKAT MUSLIM MODERNIS. Wawasan: Jurnal Ilmiah Agama Dan Sosial Budaya, 1(1).

Rohmawati, D., Islam, U., \& Sunan, N. (2019). Toleransi Beragama Perspektif Forum Komunikasi Generasi Muda Antar Umat (Tesis). PASCASARJANA UNIVERSITAS ISLAM NEGERI SUNAN AMPEL.

Roscigno, V. J., \& Yavorsky, J. E. (2015). Discrimination, diversity, and work. Routledge International Handbook of Diversity Studies, November, 274-283.

Sahlan, M. (2014). POLA INTERAKSI INTERKOMUNAL UMAT BERAGAMA DI KOTA BANDA ACEH. Substantia, 16(April), 117-136.

Shore, L. M., Randel, A. E., Chung, B. G., Dean, M. A., Ehrhart, K. H., \& Singh, G. (2011). Inclusion and diversity in work groups: A review and model for future research. In Journal of Management. https://doi.org/10.1177/0149206310385943

Sills, S.S., \& Song, C. (2002). Innovations in Survey Research: An apllication of Web-based surveys. Social Science Computer Review, 20(1), 22-30.

Siswanto, D. (2004). Sosialitas Dalam Perseptif Filsafat Sosial. Jurnal Filsafat, 1(Sosialitas), 67-87.

Supriyanto, A., \& Wahyudi, A. (2017). Skala karakter toleransi: konsep dan operasional aspek kedamaian, menghargai perbedaan dan kesadaran individu. Counsellia: Jurnal Bimbingan Dan Konseling, 7(2), 61. https://doi.org/10.25273/counsellia.v7i2.1710

Syamsuar, C. A., \& Ginting, H. (2020). Mengelola Keberagaman Pegawai Dalam Konflik Interpersonal Guna Meningkatkan Produktivitas Karyawan: Studi Komparasi. JPPM: Journal of Public Policy and Management, 2(e-ISSN: 2715-2952), 1-9.

Utami, S. R. (2017). Implementasi Nilai-Nilai Toleransi Antar Umat Beragama Pada Lembaga Pendidikan Nonmuslim (skripsi). PROGRAM STUDI PENDIDIKAN AGAMA ISLAM FAKULTAS TARBIYAH DAN ILMU KEGURUAN INSTITUT AGAMA ISLAM NEGERI (IAIN) SALATIGA.

Yuliyanto , A., Pendidikan, J., Islam, A., Tarbiyah, F., \& Ilmu, D. A. N. (2015). Beragama Terhadap Perkembangan Islam (Skripsi). JURUSAN PENDIDIKAN AGAMA ISLAM FAKULTAS TARBIYAH DAN ILMU KEGURUAN INSTITUT AGAMA ISLAM NEGERI. 